\title{
Urban Pollution Soiling Damages and Damage Functions
}

\author{
Ben-chieh Liu* and Eden S. H. Yu**
}

\section{INTRODUCTION}

The effects of air pollution as all other externalities and their damages can be classified into three categories: (1) cost of direct effects, (2) adjustment costs, and (3) market effect costs. Estimates of damages to human health by Liu and Yu (1976) among others fall into the first category of direct cost effects of air pollution. The second category of adjustment costs of air pollution constitutes the main concern of this paper.

The best known and the pioneering contribution to the estimation of soiling loss due to air pollution was constructed by O'Connor (1913) for the Mellon Institute. The $\$ 20.00$ per capita soiling cost figure estimated by O'Connor for the Pittsburgh smoke nuisance has been used as a basis for extrapolating to the $\$ 11$ billion national damage estimate. The validity of this damage estimate, often quoted by public officials, has been questioned by Jones (1969) and others on the grounds that the underlying assumption of the estimates that the air pollution level in Pittsburgh is representative of the entire nation is questionable.

The two studies of quantifying the soiling costs in the Upper Ohio River Valley and Washington, D.C. carried out by Michelson and Tourin (1966, 1968) have also attracted public attention. Their methodology is based on the hypothesis that significant soiling due to air pollution may be reflected in shortened time intervals between successive cleaning and maintenance operations. Michelson and Tourin established a positive relationship between frequency of cleaning operations and the levels of air pollution in both studies. However, the problems with the sample survey design and the lack of a statistically reliable technique cast doubt on the reliability of their findings.

Ridker (1967) conducted interurban studies to determine the relationship between per capita soiling costs and air pollution level for 144 cities in the United States. Soiling damage costs were approximated by per capita expenditures on laundry and dry cleaning services. Ridker (1967) failed to

\footnotetext{
\#The financial support under a contract from the United States Environmental Protection Agency is gratefully acknowledged. The research underlying this paper was conducted at the Midwest Research Institute. Resource support is also received by the second author from the Economics Division of the University of Oklahoma. The authors are indebted to Drs. Donald Gillette, John Jaksch and the two unknown referees for useful comments on an earlier version. However, the authors are solely responsible for any remaining shortcomings. The views expressed herein are those of the authors. They do not necessarily reflect the opinion of the sponsoring agency.

* Midwest Research Institute, 425 Volker Blvd., Kansas City, Missouri 64110.

**Economics Division, University of Oklahoma, Norman, Oklahoma 73019.
} 
detect discernable patterns between soiling costs and the suspended particulate levels whether the effects of climate, per capita income, and price differentials were controlled or not. The problem with the soiling damage estimates, as noted by Ridker himself arises from a rigid schedule for cleaning and maintenance operations and the schedule is independent of the location of the operation. This is especially true for commercial and industrial buildings. Additional problem arises from certain nonpollution factors which could not be controlled but these factors may be more important than air pollution in explaining the cleaning and maintenance procedures.

A recent study by Booz, Allen and Hamilton, Inc. (1970) has made a useful contribution to expand our knowledge about the relationship between cleaning frequency and suspended particulate levels. Specifically, the study reveals that 11 out of 27 ordinary cleaning and maintenance operations are sensitive to air-suspended particulate levels. In other words, the cleaning frequencies of about 40 percent of the major cleaning tasks are found to be positively related to the pollutant levels.

The objective of the paper is to quantify the soiling damages and to assign a monetary value to this category of pollution damages for the pollution-related cleaning operations as identified by the Booz, Allen and Hamilton researchers. A system of soiling physical damage functions which relate cleaning frequencies to air pollution levels for these pollution-related tasks will be developed. Furthermore, "average" economic damage functions for the United States metropolitan areas will be derived by relating monetary value of soiling damages to air pollution, demographic, socioeconomic, and climatological variables. It is hoped that the results presented in this paper are informative and useful for predicting pollution reduction benefits in terms of the resulting savings in the adjustment cost.

The plan of this paper is as follows: Section II contains the methodology and derivation of linear physical damage functions for depicting the effect of air suspended particulates on cleaning operation frequencies. In Section III, net as well as gross economic damages of soiling resulting from air pollution are estimated and presented separately for the 148 Standard Metropolitan Statistical Areas (SMSA's). Section IV develops economic damage functions for various types of household cleaning operations, and Section V contains the concluding remarks.

\section{DEVELOPMENT OF SOILING PHYSICAL DAMAGE FUNCTIONS: DATA AND METHODOLOGY}

Soiling is damages that result from total suspended particulates which accumulate from air pollution. It compels households, businesses, and industrial establishments to increase cleaning activities. Thus, soiling results in extra economic losses not only to households but to business and industrial firms as well. As noted above, a number of attempts have been undertaken to identify and quantify the soiling damages due to air pollution. Particularly noteworthy is a study by Booz, Allen and Hamilton, Inc. 
(1970). This study provides, as a result of an extensive sample survey, the data base useful for developing the soiling physical damage functions, which relates physical damages of soiling to air pollution levels.

The Renjerdel area around Philadelphia, Pennsylvania, was selected as the data gathering area by the Booz-Allen researchers. Frequency of cleaning by the residents was determined by a carefully developed questionnaire containing queries regarding cleaning operations and a set of self-referent statements with respect to cleaning attitudes. Among the 27 cleaning and maintenance operations, the study shows that 11 were somewhat sensitive to air-suspended particulate levels. Of these 11 cleaning tasks, only 9 were considered in this study because of the lack of certain needed cost information. A list of these nine pollution-related cleaning tasks together with the information on "average" unit cleaning costs is contained in Table 1.

The methodology for developing a system of soiling physical damage functions is succinctly delineated as follows: First, four population "blocks" for each of the nine pollution-related cleaning task were constructed in the two-dimensional space involving pollution level and cleaning frequency. The Booz-Allen researchers divided the studied area into four separate zones according to the air pollution levels. The range of the annual average particulate levels X measured in terms of $\mu \mathrm{g} / \mathrm{m}^{3}$ in the four zones were given as follows: $\mathrm{X}<75$ in Zone 1; $75<\mathrm{X}<100$ in Zone 2; $100<\mathrm{X}<$ 125 in Zone 3 and $X>125$ in Zone 4 . In other words, the suspended particulate levels vary from $75 \mu \mathrm{g} / \mathrm{m}^{3}$ to $100 \mu \mathrm{g} / \mathrm{m}^{3}$ in Zone 2 and from 100 $\mu \mathrm{g} / \mathrm{m}^{3}$ to $125 \mu \mathrm{g} / \mathrm{m}^{3}$ in Zone 3. The upper limit of the suspended particulates in Zone 1 is $75 \mu \mathrm{g} / \mathrm{m}^{3}$ and the lower limit of X in Zone 4 is $125 \mu \mathrm{g} / \mathrm{m}^{3}$. It is reasonable to assume that the suspended particulate level in the study area ranges from a lower limit of $25 \mu \mathrm{g} / \mathrm{m}^{3}$ to an upper limit of $175 \mu \mathrm{g} / \mathrm{m}^{3}$. Therefore, the pollutant level in Zone 1 would vary between $25 \mu \mathrm{g} / \mathrm{m}^{3}$ to 75 $\mu \mathrm{g} / \mathrm{m}^{3}$ and in Zone 4 would vary between $125 \mu \mathrm{g} / \mathrm{m}^{3}$ to $175 \mu \mathrm{g} / \mathrm{m}^{3}$. For convenience sake, the ranges of air pollution levels for the four sampling zones are tabulated in Table 2.

TABLE 1

Pollution-Related Tasks and Their Unit Cleaning Costs

\begin{tabular}{llc}
\hline & \multicolumn{1}{c}{ Tasks } & Unit Cleaning Costs $(\$)$ \\
\hline 1 & Replace air conditioner filter & 1.00 \\
2 & Wash floor surface & 6.00 \\
3 & Wash inside window & 0.50 \\
4 & Clean venetian blinds/shades & 3.50 \\
5 & Clean/repair screens & 0.20 \\
6 & Wash outside windows & 1.50 \\
7 & Clean/repair storm windows & 2.00 \\
8 & Clean outdoor furniture & 10.00 \\
9 & Clean gutters & 15.00 \\
\hline
\end{tabular}


Second, the range values of cleaning frequency $(\mathrm{Y})$ for the four zones were computed by adding and subtracting one standard error of the mean from the mean value of the cleaning frequency. The computed values for lower limit (Min Y) and upper limit of the cleaning frequency (Max Y), lower limit (Min X) and upper limit (Max X) of suspended particulates, coupled with the mean frequency of cleaning and the standard error of the means for the nine pollution-related tasks are presented in Appendix A. The pollution and cleaning frequency "blocks" on which the sampling experiment is conducted are bounded by the values of Min Y, Max Y, Min X and Max X.

Third, a sampling technique was applied to the four "blocks" associated with the four zones for each cleaning task. It should be pointed out that the purpose of the sampling experiment is not to force a correlation between cleaning frequency and pollution level (the correlation has already been confirmed by the prior Booz, Allen and Hamilton study), but to generate a larger set of random observations to account for possible uncertainty associated with the original data. As a result, a random sample of 160 random observations for each cleaning task was selected for regression analysis. These 160 observations were fitted via both linear and nonlinear least-squares techniques. It was found that the linear fit is superior than the nonlinear fit in all cases of cleaning operations except for Task 8. Assembling the best set of the regression results, the linear regressions for Task 1 through 7 and Task 9 and the nonlinear regression for Task 8 are summarized in Table 3. It is noteworthy that the coefficients for pollution variable are significant at the 1 percent level for all 9 cleaning operations, and the $\mathrm{R}^{2}$ ranges from 0.43 to 0.80 for the 8 linear physical damage functions and 0.26 for the nonlinear equation.

\section{SOILING ECONOMIC DAMAGES OF AIR POLLUTION}

Given the preceding nine physical damage functions for the nine pollution-related cleaning tasks and the associated unit cleaning costs which were obtained through telephone conversations with various cleaning firms in Kansas City, the economic costs of individual household adjustment to air pollution can be derived by transforming the pollutioninduced cleaning frequency into monetary units, via the following two formulas: ${ }^{1}$

\section{TABLE 2}

Ranges of Air Pollution Levels $\left(\mu \mathrm{g} / \mathrm{m}^{3}\right)$ in the Four Study Areas

\begin{tabular}{lrc}
\hline & Min X & Max X \\
\hline Zone 1 & 25 & 75 \\
Zone 2 & 75 & 100 \\
Zone 3 & 100 & 125 \\
Zone 4 & 125 & 175 \\
\hline
\end{tabular}




$$
\begin{aligned}
& \mathrm{NSCO}_{\mathrm{i}}=\mathrm{b}_{\mathrm{i}}(\mathrm{TSP}-45) \cdot \mathrm{C} \cdot \mathrm{U} \cdot \mathrm{H} \\
& \mathrm{GSCO}_{\mathrm{i}}=\mathrm{a}_{\mathrm{i}}+\mathrm{b}_{\mathrm{i}}(\mathrm{TSP}-45) \cdot \mathrm{C} \cdot \mathrm{U} \cdot \mathrm{H}
\end{aligned}
$$

where $\mathrm{NSCO}_{\mathrm{i}}$ and $\mathrm{GSCO}_{\mathrm{i}}$ are, respectively, the net (extra) and gross soiling damage cost for the ith type of cleaning task. Parameters $a_{i}$ and $b_{i}(i=1$, . . . . 9) are the estimated coefficients in the physical damage functions as shown in Table 3. Variables $\mathrm{C}, \mathrm{U}$ and $\mathrm{H}$ stand for the unit cleaning cost, number of cleaning objects per household and number of households in a metropolitan area, respectively.

To measure the "real" effect of suspended particulates on soiling damages, the suspended particulate level was adjusted by a threshold level because a low level of suspended particulate might have a negligible effect on the household cleaning activities. A threshold level of $45 \mu \mathrm{g} / \mathrm{m}^{3}$ for suspended particulate was assumed as the background concentration level in this study because the lowest 1970 annual mean level for total suspended particulates was $46.7 \mu \mathrm{g} / \mathrm{m}^{3}$ for Charleston, South Carolina. Alternative reasonable threshold levels can also be used for estimating soiling costs. It

TABLE 3

\begin{tabular}{|c|c|c|c|}
\hline \multicolumn{4}{|c|}{ A. Frequency $=a+b$ TSP } \\
\hline Task & a & $\mathrm{b}$ & $\mathrm{R}^{2}$ \\
\hline 1 & $\begin{array}{c}0.03 \\
(0.05)\end{array}$ & $\begin{array}{c}0.00510 \\
(0.00048)^{*}\end{array}$ & 0.43 \\
\hline 2 & $\begin{array}{l}38.6 \\
(0.18)\end{array}$ & $\begin{array}{c}0.0400 \\
(0.0017) *\end{array}$ & 0.80 \\
\hline 3 & $\begin{array}{c}5.6 \\
(0.4)\end{array}$ & $\begin{array}{c}0.078 \\
(0.036) *\end{array}$ & 0.76 \\
\hline 4 & $\begin{array}{c}2.3 \\
(0.2)\end{array}$ & $\begin{array}{c}0.048 \\
(0.002) *\end{array}$ & 0.79 \\
\hline 5 & $\begin{array}{c}0.42 \\
(0.06)\end{array}$ & $\begin{array}{c}0.0059 \\
(0.0049)^{*}\end{array}$ & 0.48 \\
\hline 6 & $\begin{array}{c}1.00 \\
(0.28)\end{array}$ & $\begin{array}{c}0.0530 \\
(0.0025) *\end{array}$ & 0.74 \\
\hline 7 & $\begin{array}{c}0.85 \\
(0.15)\end{array}$ & $\begin{array}{c}0.015 \\
(0.001)^{*}\end{array}$ & 0.48 \\
\hline 9 & $\begin{array}{c}0.27 \\
(0.12)\end{array}$ & $\begin{array}{c}0.0140 \\
(0.0011)^{*}\end{array}$ & 0.55 \\
\hline \multicolumn{4}{|c|}{ B. Frequency $=c+e^{(a-b / T S P)}$} \\
\hline $\begin{array}{c}8 \\
(\mathrm{c}=2)\end{array}$ & $\begin{array}{c}0.67 \\
(0.10)\end{array}$ & $\begin{array}{c}53.2 \\
(7.4)^{*}\end{array}$ & 0.26 \\
\hline
\end{tabular}

Soiling Physical Damage Functions ${ }^{\mathrm{a} /}$ 
is worth pointing out that, other things being equal, a higher threshold level is generally associated with a lower damage cost, and the marginal changes in the damage cost in response to a unit change in the threshold level is the value of $b_{i}$ for the ith type of cleaning task.

Given the data collected from official publications and telephone interviews for the variables in the formulae (7) and (8), the net and gross household soiling costs for each of the nine cleaning operations by the 65 large SMSA's (with population greater than 500,000) and by the 83 medium SMSA's (200,000 to 500,000 people) were derived. ${ }^{2}$ The detailed soiling damage estimates by cleaning operations and SMSA's will be furnished upon request from the readers. The findings reveal that Chicago, New York, and Los Angeles, in order of magnitude, suffered the most in terms of total net soiling damages. The net soiling damages in these three SMSA's in 1970 are, respectively, $\$ 516$ million, $\$ 418$ million, and $\$ 388$ million. It is also noteworthy that the cleaning activities of Tasks 4 and 6 resulted in an economic damage of about $\$ 2$ billion and $\$ 1$ billion, respectively, in the 148 metropolitan areas. These two tasks constituted the largest damage categories among the nine pollution-related cleaning tasks.

Per capita net and gross soiling damage costs in the presence of air pollution for large SMSA's and medium SMSA's for 1970 were also computed. The per capita cost figures, available to readers upon request, indicate that the soiling damages attributable to air pollution in large SMSA's range from $\$ 5$ per person in San Antonio, Texas, to $\$ 104$ per person in Cleveland, Ohio, whereas the net soiling damages in medium SMSA's vary from less than a dollar per person in Charleston, South Carolina, to $\$ 67.35$ per person in Wichita, Kansas. These damage estimates of soiling for individual SMSA's appear to be much more realistic than the overall per capita damage estimates of $\$ 20.00$ by Mellon Institute and of $\$ 200$ by Michelson and Tourin.

A summary of the net and gross soiling damages by cleaning operations is contained in Table 4. The total net soiling damage as a result of falling suspended particulates for the 148 SMSA's in 1970 amounts to $\$ 5$ billion. This damage figure is far smaller than the $\$ 11$ billion and $\$ 30$ billion national estimate extrapolated from the per capita damage figures reported respectively in the Mellon Institute study and the study by Michelson and Tourin. The validity of the $\$ 11$ billion and $\$ 30$ billion estimates, as noted earlier, are seriously undermined by the assumptions used in the extrapolation. Regarding the gross soiling damage costs, New York, Chicago and Los Angeles had the highest damages among the 148 large SMSA's, about $\$ 1.6$ billion, $\$ 1.2$ billion, and $\$ 1.1$ billion, respectively, partially because of the relatively high suspended particulate levels and a large number of household units in these three cities. Total gross soiling damage which is the sum of soiling damages attributable to air pollution and other factors amounts to $\$ 17.4$ billion per year for the 148 SMSA's.

Regarding the use of the regional soiling damage costs and the national damage costs derived in this study, a caveat is in order. The damage costs should be used only as crude estimates because of the possible violation of 
the two assumptions employed in our model: (1) the physical damage functions developed for the Philadelphia area are "representative" of the physical damage functions of the 148 SMSA's; (2) the unit cleaning cost figures obtained in the Kansas City area are applicable to other SMSA's.

\section{SOILING ECONOMIC DAMAGE FUNCTIONS}

In order to develop "average" soiling economic damage functions for each of the nine cleaning tasks, the individual metropolitan damage costs were regressed against not only the TSP, but also to various socioeconomic, demographic, and climatological characteristics of various regions. The stepwise regression technique was used with inputs from the 148 sample observations for estimating the economic damage functions. The regression results are summarized in Table 5 . The variable $\mathrm{GSCO}_{\mathrm{i}}$ denotes the gross soiling damage cost of the ith type of the cleaning operation, $\mathrm{i}=1$, $2, \ldots, 9$. TGSCO is the total gross soiling cost, i.e., the sum of $\mathrm{GSCO}_{\mathrm{i}}$ over i. Seven independent variables were selected to represent the socioeconomic, demographic and climatological characteristics. The variable MANFV denotes the value of manufacturing output, TSP the total suspended particulate level $\left(\mu \mathrm{g} / \mathrm{m}^{3}\right)$, PCOL the percentage of persons 25 or older who have completed 4 years of college, RHM the relative humidity, DTS the numbers of days with thunderstorms, PDS, the population density in the SMSA, PAGE the percentage of population that is more than 65 years old and the parameter a is the intercept. It is noteworthy that all the coefficients of TSP are of correct signs except the one in the second regression equation. Since the partial correlation coefficient between GSCO2 and TSP is positive and equal to 0.18 , the negative coefficient obtained for TSP in the regression equation may be attributable to multicolinearity and other econometric problems.

The soiling economic damage functions derived here are useful to

TABLE 4

Net and Gross Soiling Damage Costs in 148 SMSA's by Cleaning Operations, 1970

\begin{tabular}{cccc}
\hline Tasks & $\begin{array}{c}\text { Net } \\
\text { Soiling Damages } \\
\text { (million \$) }\end{array}$ & $\begin{array}{c}\text { Gross } \\
\text { Soiling Damages } \\
\text { (million \$) }\end{array}$ & $\begin{array}{c}\text { Net/Gross } \\
\text { Soiling Damages } \\
\text { Cost }\end{array}$ \\
\hline 1 & 11.8 & 12.8 & 0.91 \\
2 & 558.8 & $9,884.9$ & 0.05 \\
3 & 454.1 & 204.0 & 0.45 \\
4 & $1,956.3$ & $3,584.1$ & 0.55 \\
5 & 13.6 & 30.6 & 0.44 \\
6 & 925.7 & $1,227.9$ & 0.75 \\
7 & 349.2 & 691.6 & 0.50 \\
8 & 275.1 & $1,079.2$ & 0.25 \\
9 & 488.9 & 652.0 & 0.75 \\
Total & $5,033.0$ & $17,367.1$ & 0.28 \\
\hline
\end{tabular}


TABLE 5

Soiling Economic Damage Functions ${ }^{\mathrm{a}}$

\begin{tabular}{|c|c|c|c|c|c|c|c|c|c|}
\hline $\begin{array}{l}\text { Dependent } \\
\text { Variable }\end{array}$ & MANFV & TSP & PCOL & RHM & DTS & PDS & PAGE & a & $\mathrm{R}^{2}$ \\
\hline GSC01 & $\begin{array}{c}66.18 \\
(2.02)^{*}\end{array}$ & $\begin{array}{c}1,128.83 \\
(147.36)^{*}\end{array}$ & $\begin{array}{l}2,377.55 \\
(1,288.8)\end{array}$ & $\begin{array}{c}-995.17 \\
(538.89)\end{array}$ & $\begin{array}{c}271.69 \\
(193.52)\end{array}$ & $\begin{array}{l}-1.78 \\
(3.81)\end{array}$ & $\begin{array}{c}764.7 \\
(1,940.9)\end{array}$ & $\begin{array}{l}-100,181.3 \\
(46,192.6)\end{array}$ & 0.92 \\
\hline GSC02 & $\begin{array}{c}42.9 \\
(1.45)^{*}\end{array}$ & $\begin{array}{l}-108.5 \\
(105.5)\end{array}$ & $\begin{array}{l}2,252.2 \\
(915.7)^{*}\end{array}$ & $\begin{array}{c}670.6 \\
(383.4)\end{array}$ & & $\begin{array}{c}2.2 \\
(2.7)\end{array}$ & $\begin{array}{c}2,401.1 \\
(1,392.6)\end{array}$ & $\begin{array}{c}5,400.0 \\
(32,763.0)\end{array}$ & 0.89 \\
\hline GSC03 & $\begin{array}{c}957.6 \\
(25.9)^{*}\end{array}$ & $\begin{array}{c}6,802.6 \\
(1,887.5)^{*}\end{array}$ & $\begin{array}{c}42,426.0 \\
(16,507.0)^{*}\end{array}$ & $\begin{array}{c}-14,677.0 \\
(6,902.0)^{*}\end{array}$ & $\begin{array}{c}1,946.0 \\
(2,478.0)\end{array}$ & $\begin{array}{c}12.4 \\
(48.9)\end{array}$ & $\begin{array}{c}32,626.0 \\
(24,859.0)\end{array}$ & $\begin{array}{c}652,046.0 \\
(591,650.0)\end{array}$ & 0.93 \\
\hline GSC04 & $\begin{array}{c}17.2 \\
(0.42)^{*}\end{array}$ & $\begin{array}{c}160.0 \\
(33.1)^{*}\end{array}$ & $\begin{array}{c}727.4 \\
(292.3) *\end{array}$ & $\begin{array}{c}-262.6 \\
(122.4)^{*}\end{array}$ & $\begin{array}{c}42.577 \\
(43.8)\end{array}$ & & $\begin{array}{c}501.9 \\
(439.4)\end{array}$ & $\begin{array}{c}14,825.0 \\
(10,445.0)\end{array}$ & 0.93 \\
\hline GSC05 & $\begin{array}{c}144.3 \\
(3.90)^{*}\end{array}$ & $\begin{array}{c}1,031.6 \\
(284.2)^{*}\end{array}$ & $\begin{array}{c}6,384.9 \\
(2,485.6)^{*}\end{array}$ & $\begin{array}{c}-2,210.7 \\
(1,039.3)^{*}\end{array}$ & $\begin{array}{c}294.6 \\
(373.2)\end{array}$ & $\begin{array}{c}1.85 \\
(7.36)\end{array}$ & $\begin{array}{c}4,898.9 \\
(3,743.2)\end{array}$ & $\begin{array}{c}98,799.0 \\
(89,087.0)\end{array}$ & 0.93 \\
\hline GSC06 & $\begin{array}{c}6.12 \\
(0.17) *\end{array}$ & $\begin{array}{c}84.0 \\
(12.5)^{*}\end{array}$ & $\begin{array}{c}236.9 \\
(109.9)^{*}\end{array}$ & $\begin{array}{c}-92.6 \\
(45.9)^{*}\end{array}$ & $\begin{array}{c}20.9 \\
(16.5)\end{array}$ & $\begin{array}{l}-0.083 \\
(0.325)\end{array}$ & $\begin{array}{c}116.6 \\
(165.6)\end{array}$ & $\begin{array}{l}-7,565.5 \\
(3,941.2)\end{array}$ & 0.93 \\
\hline GSC07 & $\begin{array}{c}3.29 \\
(0.08)^{*}\end{array}$ & $\begin{array}{l}27.7 \\
(6.4)^{*}\end{array}$ & $\begin{array}{c}142.0 \\
(56.3)^{*}\end{array}$ & $\begin{array}{c}-50.3 \\
(23.5)^{*}\end{array}$ & $\begin{array}{c}7.6 \\
(8.4)\end{array}$ & $\begin{array}{c}0.025 \\
(0.166)\end{array}$ & $\begin{array}{c}102.2 \\
(84.8)\end{array}$ & $\begin{array}{l}-2,607.0 \\
(2,018.7)\end{array}$ & 0.93 \\
\hline GSC08 & $\begin{array}{c}4.92 \\
(0.15) *\end{array}$ & $\begin{array}{c}9.07 \\
(10.9)\end{array}$ & $\begin{array}{c}223.0 \\
(94.9)^{*}\end{array}$ & $\begin{array}{l}-74.8 \\
(39.7)\end{array}$ & & $\begin{array}{c}0.17 \\
(0.28)\end{array}$ & $\begin{array}{c}212.9 \\
(144.4)\end{array}$ & $\begin{array}{c}877.7 \\
(3,396.3)\end{array}$ & 0.91 \\
\hline GSC09 & $\begin{array}{c}3.23 \\
(0.08)^{*}\end{array}$ & $\begin{array}{l}44.6 \\
(6.5)^{*}\end{array}$ & $\begin{array}{c}126.9 \\
(579.4)^{*}\end{array}$ & $\begin{array}{c}-48.9 \\
(24.2)^{*}\end{array}$ & $\begin{array}{l}11.2 \\
(8.6)\end{array}$ & & $\begin{array}{c}60.4 \\
(87.0)\end{array}$ & $\begin{array}{c}4,047.7 \\
(2,070.1)\end{array}$ & 0.93 \\
\hline $\mathrm{TGSCO}^{\mathrm{b}}$ & $\begin{array}{c}78.9 \\
(2.3)^{*}\end{array}$ & $\begin{array}{c}226.4 \\
(166.9)\end{array}$ & $\begin{array}{c}3,766.0 \\
(1,460.0)^{*}\end{array}$ & $\begin{array}{l}-1,219.8 \\
(610.7)^{*}\end{array}$ & $\begin{array}{c}90.9 \\
(219.3)\end{array}$ & $\begin{array}{c}2.3 \\
(4.3)\end{array}$ & $\begin{array}{c}3,432.3 \\
(2,199.5)\end{array}$ & $\begin{array}{l}-25,621.0 \\
(52,347.0)\end{array}$ & 0.92 \\
\hline
\end{tabular}

a /All coefficients and standard errors are reduced by a factor of $10^{3}$, except equation GSC01, GSC03 and GSC05. The standard errors are the values below the coefficients, and $*$ indicates that the coefficient is significant at the 1 percent level. 
policy-makers at either the local or national level in estimating the marginal and average benefits of implementing pollution abatement programs. The responsiveness of gross soiling damages for a particular cleaning task to changes in climatological, demographic, and socioeconomic variables and the concentration level of suspended particulates can be easily estimated. Of particular policy interest is the estimation of possible benefit in terms of the reduction in the overall soiling damage cost as a result of a pollution control program. Note that the coefficient of TSP in the overall soiling economic damage function is 226,400 and the mean value of overall soiling damage is $\$ 117.3$ million. Given that the mean value of TSP $=94.5$ $\mu \mathrm{g} / \mathrm{m}^{3}$, the elasticity of soiling cost with respect to pollution level is computed as follows:

$$
\mathrm{E}_{\mathrm{SC}, \mathrm{TSP}}=226400 \times(94.5 / 117.3000000)=0.18
$$

Thus, if the suspended particulate level is lowered, on the average, by 10 percent, from 94.5 to $85.5 \mu \mathrm{g} / \mathrm{m}^{3}$, overall gross soiling damage cost would reduce by 1.8 percent or by $\$ 2.1$ million, from $\$ 117.3$ million to $\$ 115.2$ million.

\section{CONCLUDING REMARKS}

An attempt has been in the preceding analysis to develop a system of soiling physical damage functions by relating nine types of cleaning frequencies to air pollution. Furthermore, national "average" economic damage functions for various household soiling chores were developed by regressing soiling damages to air pollution and other relevant demographic, socioeconomic, and climatological variables. Based on the physical and the economic pollution soiling damage functions, the net and gross soiling damage costs for the 148 selected SMSA's with population exceeding 250,000 were estimated. We found that total net soiling costs attributable to air pollution over the 148 SMSA's amounted to more than $\$ 5$ billion, and total gross soiling costs were about $\$ 17$ billion over the 148 SMSA's. An example involving the calculation of the pollution elasticity of household soiling damages is given to illustrate the use of the economic damage function for predicting possible benefits of various pollution control programs. It is shown that a 10 percent reduction in the urban suspended particulate level would result in a saving of exceeding 2 million dollars in the United States.

\section{FOOTNOTES}

${ }^{1}$ For Task $8, \mathrm{NSCO} 8=\mathrm{e}^{0.85-0.015 /(\mathrm{TSP}-45)} \cdot \mathrm{C} \cdot \mathrm{U} \cdot \mathrm{H}$ and

${ }^{2}$ For a detailed listing of the 148 large and medium $\mathrm{GSCO} 8=2+\mathrm{e}^{0.85-0.015 /(\mathrm{TSP}-45)} \cdot \mathrm{C} \cdot \mathrm{U} \cdot \mathrm{H}$ SMSA's included in this study, see Appendix B.

\section{REFERENCES}

1. Booz-Allen and Hamilton, Incorporated, Study to Determine Residential Soiling Costs of Particulate Air Pollution, Washington, D.C., October 1970.

2. Jones, A. Craig, "Studies to Determine the Costs of
Soiling Due to Air Pollution: An Evaluation, ${ }^{n}$ in: Economics of Air and Water Pollution, Virginia Polytechnic Institute, Water Resources Center, Blacksburg, Virginia, April 1969. 
3. Liu, Ben-Chieh, and Eden S.H. Yu, "Mortality and Air Pollution: Revisited," Journal of Air Pollution Control Association, September 1976.

4. Liu, Ben-Chieh, and Eden S.H. Yu, Air Pollution Damage Functions and Regional Damage Estimates, Technomic Publishing Co. 1977.

5. Michelson, Irving and Boris Tourin, "Comparative Method for Studying Costs of Air Pollution," Public Health Report, 81, June 1966.

6. Michelson, Irving and Boris Tourin, The Household
Costs of Air Pollution in Connecticut, the Connecticut State Department of Health and Environmental Health and Safety Research Associate, Hartford, Connecticut, October 1968.

7. O'Connor, John J., Jr., The Economic Cost of the Smoke Nuisance to Pittsburgh, Mellon Institute of Industrial Research and School of Specific Industries, University of Pittsburgh, Pittsburgh, Pennsylvania (1913).

8. Ridker, Ronald G., Economic Costs of Air Pollution (New York: Frederick A. Praeger. 1967).

\section{APPENDIX A}

Mean Frequency, Standard Error and Upper And Lower Limits of Frequency

And Suspended Particulates

Task 1

Zone 1

Zone 2

Zone 3

Zone 4

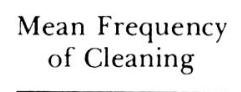

Standard Error
of Means

\begin{tabular}{c} 
of Means \\
\hline 0.06 \\
0.08 \\
0.07 \\
0.34
\end{tabular}

\begin{tabular}{|c|c|c|c|}
\hline $\operatorname{Min} Y$ & $\operatorname{Max} Y$ & $\operatorname{Min} \mathrm{X}$ & $\operatorname{Max} X$ \\
\hline 0.30 & 0.42 & 25 & 75 \\
\hline 0.42 & 0.58 & 75 & 100 \\
\hline 0.23 & 0.37 & 100 & 125 \\
\hline 0.64 & 1.32 & 125 & 175 \\
\hline
\end{tabular}

$39.71-41.39$

$41.22 \quad 42.90$

$41.77 \quad 43.72$

$44.24 \quad 46.10$

$\begin{array}{rr}25 & 75 \\ 75 & 100 \\ 100 & 125 \\ 125 & 175\end{array}$

$\begin{array}{llll}9.45 & 10.17 & 25 & 75\end{array}$

$\begin{array}{llll}11.08 & 12.48 & 75 & 100\end{array}$

$\begin{array}{llll}11.93 & 13.55 & 100 & 125\end{array}$

$\begin{array}{llll}17.85 & 20.05 & 125 & 175\end{array}$

Task 3

Zone 1

Zone 2

Zone 3

Zone 4

Task 4

Zone 1

Zone 2

Zone 3

Zone 4

10.06

11.78

12.74

18.45
0.61

0.70

0.82

1.10

0.53

0.66

0.91

0.49
3.51

5.51

8.22

8.22
4.57

6.87

10.04

10.20
25

75

100

125
75

100

125

175

Task 5

$\begin{array}{rrrrrrr}\text { Zone 1 } & 0.80 & 0.07 & 0.75 & 0.87 & 25 & 75 \\ \text { Zone 2 } & 0.93 & 0.16 & 0.77 & 1.09 & 75 & 100 \\ \text { Zone 3 } & 0.79 & 0.10 & 0.70 & 0.86 & 100 & 125 \\ \text { Zone 4 } & 1.50 & 0.32 & 1.18 & 1.82 & 125 & 175\end{array}$

Task 6

\begin{tabular}{rrrrrrr} 
Zone 1 & 4.25 & 0.35 & 3.90 & 4.60 & 25 & 75 \\
Zone 2 & 4.59 & 0.38 & 4.21 & 4.97 & 75 & 100 \\
Zone 3 & 6.17 & 0.60 & 5.57 & 6.77 & 100 & 125 \\
Zone 4 & 10.09 & 0.88 & 9.21 & 10.97 & 125 & 175 \\
\hline
\end{tabular}


APPENDIX A (Concluded)

\begin{tabular}{|c|c|c|c|c|c|c|}
\hline & $\begin{array}{c}\text { Mean Frequency } \\
\text { of Cleaning }\end{array}$ & $\begin{array}{c}\text { Standard Error } \\
\text { of Means }\end{array}$ & $\operatorname{Min} Y$ & $\operatorname{Max} Y$ & $\operatorname{Min} \mathrm{X}$ & $\operatorname{Max} X$ \\
\hline \multicolumn{7}{|l|}{ Task 7} \\
\hline Zone 1 & 2.07 & 0.28 & 1.79 & 2.35 & 25 & 75 \\
\hline Zone 2 & 1.60 & 0.23 & 1.37 & 1.83 & 75 & 100 \\
\hline Zone 3 & 2.12 & 0.39 & 1.73 & 2.51 & 100 & 125 \\
\hline Zone 4 & 3.69 & 0.63 & 3.60 & 4.32 & 125 & 175 \\
\hline \multicolumn{7}{|l|}{ Task 8} \\
\hline Zone 1 & 2.50 & 0.45 & 2.05 & 2.95 & 25 & 75 \\
\hline Zone 2 & 4.29 & 0.65 & 3.64 & 4.94 & 75 & 100 \\
\hline Zone 3 & 3.52 & 0.71 & 2.81 & 4.23 & 100 & 125 \\
\hline Zone 4 & 1.19 & 0.47 & 0.72 & 1.66 & 125 & 175 \\
\hline \multicolumn{7}{|l|}{ Task 9} \\
\hline Zone 1 & 1.12 & 0.22 & 0.91 & 1.34 & 25 & 75 \\
\hline Zone 2 & 1.54 & 0.33 & 1.21 & 1.87 & 75 & 100 \\
\hline Zone 3 & 1.35 & 0.44 & 0.91 & 1.79 & 100 & 125 \\
\hline Zone 4 & 2.80 & 0.69 & 2.11 & 3.49 & 125 & 175 \\
\hline
\end{tabular}

\section{APPENDIX B}

SMSA'S with Population over 500,000 (L)

\begin{tabular}{|c|c|c|c|}
\hline & $\underline{\text { SMSA }}$ & $\underline{\text { Code }}$ & $\begin{array}{l}\text { Population, } 1970 \\
\quad \text { (in } 1,000)\end{array}$ \\
\hline 1 & Akron, Ohio & AKR & 679 \\
\hline 2 & Albany-Schenectady-Troy, N.Y. & ALB & 721 \\
\hline 3 & Allentown-Bethlehem-Easton, Pa.-N.J. & ALL & 544 \\
\hline 4 & Anaheim-Santa Ana-Garden Grove, Calif. & ANA & 1,420 \\
\hline 5 & Atlanta, Ga. & ATL & 1,390 \\
\hline 6 & Baltimore, Md. & BAL & 2,071 \\
\hline 7 & Birmingham, Ala. & BIR & 739 \\
\hline 8 & Boston, Mass. & BOS & 2,754 \\
\hline 9 & Buffalo, N.Y. & BUF & 1,349 \\
\hline 10 & Chicago, Ill. & $\mathrm{CHI}$ & 6,979 \\
\hline 11 & Cincinnati, Ohio-Ky.-Ind. & CIN & 1,385 \\
\hline 12 & Cleveland, Ohio & CLE & 2,064 \\
\hline 13 & Columbus, Ohio & $\mathrm{COL}$ & 916 \\
\hline 14 & Dallas, Texas & $\mathrm{DAL}$ & 1,556 \\
\hline 15 & Dayton, Ohio & DAY & 850 \\
\hline 16 & Denver, Colo. & DEN & 1,228 \\
\hline 17 & Detroit, Mich. & DET & 4,200 \\
\hline 18 & Fort Lauderdale-Hollywood, Fla. & FOR & 620 \\
\hline 19 & Fort Worth, Texas & FOR & 762 \\
\hline 20 & Gary-Hammond-East Chicago, Ind. & GAR & 633 \\
\hline 21 & Grand Rapids, Mich. & GRA & 539 \\
\hline 22 & $\begin{array}{l}\text { Greensboro-Winston-Salem-High Point, } \\
\text { N.C. }\end{array}$ & GRE & 604 \\
\hline
\end{tabular}




\section{APPENDIX B}

SMSA'S with Population over 500,000 (L)

\begin{tabular}{|c|c|c|c|}
\hline & $\underline{\text { SMSA }}$ & Code & $\begin{array}{l}\text { Population, 1970) } \\
\quad \text { (in } 1,000)\end{array}$ \\
\hline 23 & Hartford, Conn. & HAR & 664 \\
\hline 24 & Honolulu, Hawaii & HON & 629 \\
\hline 25 & Houston, Texas & HOU & 1,985 \\
\hline 26 & Indianapolis, Ind. & IND & 1,110 \\
\hline 27 & Jacksonville, Fla. & JAC & 529 \\
\hline 28 & Jersey City, N.J. & JER & 609 \\
\hline 29 & Kansas City, Mo.-Kans. & KAN & 1,254 \\
\hline 30 & Los Angeles-Long Beach, Calif. & LOS & 7,032 \\
\hline 31 & Louisville, Ky.-Ind. & LOU & 827 \\
\hline 32 & Memphis, Tenn.-Ark. & MEM & 770 \\
\hline 33 & Miami, Fla. & MIA & 1,268 \\
\hline 34 & Milwaukee, Wis. & MIL & 1,404 \\
\hline 35 & Minneapolis-St. Paul, Minn. & MIN & 1,814 \\
\hline 36 & Nashville-Davidson, Tenn. & NAS & 541 \\
\hline 37 & New Orleans, La. & NEW & 1,046 \\
\hline 38 & New York, N.Y. & NEW & 11,529 \\
\hline 39 & Newark, N.J. & NEW & 1,857 \\
\hline 40 & Norfolk-Portsmouth, Va. & NOR & 681 \\
\hline 41 & Oklahoma City, Okla. & OKL & 641 \\
\hline 42 & Omaha, Nebraska-Iowa & OMA & 540 \\
\hline 43 & Paterson-Clifton-Passaic, N.J. & PAT & 1,359 \\
\hline 44 & Philadelphia, Pa.-N.J. & PHI & 4,818 \\
\hline 45 & Phoenix, Ariz. & $\mathrm{PHO}$ & 968 \\
\hline 46 & Pittsburgh, Pa. & PIT & 2,401 \\
\hline 47 & Portland, Oreg.-Wash. & POR & 1,009 \\
\hline 48 & Providence-Pawtucket-Warwick, R.I. -Mass. & PRO & 911 \\
\hline 49 & Richmond, Va. & RIC & 518 \\
\hline 50 & Rochester, N.Y. & ROC & 883 \\
\hline 51 & Sacramento, Calif. & $\mathrm{SAC}$ & 801 \\
\hline 52 & St. Louis, Mo.-Ill. & STL & 2,363 \\
\hline 53 & Salt Lake City, Utah & SAL & 558 \\
\hline 54 & San Antonio, Texas & SAN & 864 \\
\hline 55 & San Bernadino-Riverside-Ontario, Calif. & SAN & 1,143 \\
\hline 56 & San Diego, Calif. & SAN & 1,358 \\
\hline 57 & San Francisco-Oakland, Calif. & SAN & 3,110 \\
\hline 58 & San Jose, Calif. & SÁN & 1,065 \\
\hline 59 & Seattle-Everett, Wash. & SEA & 1,422 \\
\hline 60 & Springfield-Chicopee-Holyoke, Mass.-Conn. & SPR & 530 \\
\hline 61 & Syracuse, N.Y. & SYR & 636 \\
\hline 62 & Tampa-St. Petersburg, Fla. & TAM & 1,013 \\
\hline 63 & Toledo, Ohio-Mich. & TOL & 693 \\
\hline 64 & Washington, D.C.-Md.-Va. & WAS & 2,861 \\
\hline 65 & Youngstown-Warren, Ohio & YOU & 536 \\
\hline
\end{tabular}




\section{APPENDIX B}

SMSA'S with Population 200,000-500,000 (M)

\begin{tabular}{|c|c|c|c|}
\hline & SMSA & Code & $\begin{array}{l}\text { Population, } 1970 \\
\quad \text { (in } 1,000)\end{array}$ \\
\hline 66 & Albuquerque, N. Mex & ALB & 316 \\
\hline 67 & Ann Arbor, Mich. & ANN & 234 \\
\hline 68 & Appleton-Oshkosh, Wis. & APP & 277 \\
\hline 69 & Augusta, Ga.-S.C. & AUG & 253 \\
\hline 70 & Austin, Texas & AUS & 296 \\
\hline 71 & Bakersfield, Calif. & $\mathrm{BAK}$ & 329 \\
\hline 72 & Baton Rouge, La. & BAT & 285 \\
\hline 73 & Beaumont-Port Authur-Orange, Texas & $\mathrm{BEA}$ & 316 \\
\hline 74 & Binghamton, N.Y.-Pa. & BIN & 303 \\
\hline 75 & Bridgeport, Conn. & BRI & 389 \\
\hline 76 & Canton, Ohio & CAN & 372 \\
\hline 77 & Charleston, S.C. & $\mathrm{CHA}$ & 304 \\
\hline 78 & Charleston, W. Va. & $\mathrm{CHA}$ & 230 \\
\hline 79 & Charlotte, N.C. & $\mathrm{CHA}$ & 409 \\
\hline 80 & Chattanooga, Tenn.-Ga. & $\mathrm{CHA}$ & 305 \\
\hline 81 & Colorado Springs, Colo. & $\mathrm{COL}$ & 236 \\
\hline 82 & Columbia, S.C. & $\mathrm{COL}$ & 323 \\
\hline 83 & Columbus, Ga.-Ala. & COL & 239 \\
\hline 84 & Corpus Christi, Texas & COR & 285 \\
\hline 85 & Davenport-Rock Island-Moline, Iowa-Ill. & DAV & 363 \\
\hline 86 & Des Moines, Iowa & DES & 286 \\
\hline 87 & Duluth-Superior, Minn.-Wis. & DUL & 265 \\
\hline 88 & El Paso, Tex. & ELP & 359 \\
\hline 89 & Erie, Pa. & ERI & 264 \\
\hline 90 & Eugene, Oreg. & EUG & 213 \\
\hline 91 & Evansville, Ind.-Ky. & EVA & 233 \\
\hline 92 & Fayetteville, N.C. & FAY & 212 \\
\hline 93 & Flint, Mich. & FLI & 497 \\
\hline 94 & Fort Wayne, Ind. & FOR & 280 \\
\hline 95 & Fresno, Calif. & FRE & 413 \\
\hline 96 & Greenville, S.C. & GRE & 300 \\
\hline 97 & Hamilton-Middleton, Ohio & HAM & 226 \\
\hline 98 & Harrisburg, Pa. & HAR & 411 \\
\hline 99 & Huntington-Ashland, W. Va.-Ky.-Ohio & HUN & 254 \\
\hline 100 & Huntsville, Ala. & HUN & 228 \\
\hline 101 & Jackson, Miss. & JAC & 259 \\
\hline 102 & Johnstown, Pa. & $\mathrm{JOH}$ & 263 \\
\hline 103 & Kalamazoo, Mich. & KAL & 202 \\
\hline 104 & Knoxville, Tenn. & $\mathrm{KNO}$ & 400 \\
\hline 105 & Lancaster, Pa. & LAN & 320 \\
\hline 106 & Lansing, Mich. & LAN & 378 \\
\hline 107 & Las Vegas, Nev. & LAS & 273 \\
\hline 108 & Lawrence-Haverhill, Mass.-N.H. & LAW & 232 \\
\hline 109 & Little Rock-North Little Rock, Ark. & LIT & 323 \\
\hline
\end{tabular}


APPENDIX B (Concluded)

SMSA'S with Population 200,000-500,000 (M)

\begin{tabular}{|c|c|c|c|}
\hline & SMSA & Code & $\begin{array}{l}\text { Population, } 1970 \\
\quad \text { (in } 1,000)\end{array}$ \\
\hline 110 & Lorain-Elyria, Ohio & LOR & 257 \\
\hline 111 & Lowell, Mass. & LOW & 213 \\
\hline 112 & Macon, Ga. & MAC & 206 \\
\hline 113 & Madison, Wis. & MAD & 290 \\
\hline 114 & Mobile, Ala. & MOB & 377 \\
\hline 115 & Montgomery, Ala. & MON & 201 \\
\hline 116 & New Haven, Conn. & NEW & 356 \\
\hline 117 & New London-Groton-Norwich, Conn. & NEW & 208 \\
\hline 118 & Newport News-Hampton, Va. & NEW & 292 \\
\hline 119 & Orlando, Fla. & ORL & 428 \\
\hline 120 & Oxnard-Ventura, Calif. & OXN & 376 \\
\hline 121 & Pensacola, Fla. & PEN & 243 \\
\hline 122 & Peoria, Ill. & PED & 342 \\
\hline 123 & Raleigh, N.C. & RAL & 228 \\
\hline 124 & Reading, Pa. & REA & 296 \\
\hline 125 & Rockford, Ill. & ROC & 272 \\
\hline 126 & Saginaw, Mich. & SAG & 220 \\
\hline 127 & Salinas-Monterey, Calif. & SAL & 250 \\
\hline 128 & Santa Barbara, Calif. & SAN & 264 \\
\hline 129 & Santa Rosa, Calif. & SAN & 205 \\
\hline 130 & Scranton, Pa. & SCR & 234 \\
\hline 131 & Shreveport, La. & SHR & 295 \\
\hline 132 & South Bend, Ind. & SOU & 280 \\
\hline 133 & Spokane, Wash. & SPO & 287 \\
\hline 134 & Stamford, Conn. & STA & 206 \\
\hline 135 & Stockton, Calif. & STO & 290 \\
\hline 136 & Tacoma, Wash. & TAC & 411 \\
\hline 137 & Trenton, N.J. & TRE & 304 \\
\hline 138 & Tucson, Ariz. & TUC & 352 \\
\hline 139 & Tulsa, Okla. & TUL & 477 \\
\hline 140 & Utica-Rome, N.Y. & UTI & 340 \\
\hline 141 & Vallejo-Napa, Calif. & VAL & 249 \\
\hline 142 & Waterbury, Conn. & WAT & 209 \\
\hline 143 & West Palm Beach, Fla. & WES & 349 \\
\hline 144 & Wichita, Kans. & WIC & 389 \\
\hline 145 & Wilkes-Barre-Hazleton, Pa. & WIL & 342 \\
\hline 146 & Wilmington, Del.-N.J.-Md. & WIL & 499 \\
\hline 147 & Worcester, Mass. & WOR & 344 \\
\hline 148 & York, Pa. & YOR & 330 \\
\hline
\end{tabular}

